\title{
Water footprint assessment of the Colombian cocoa production
}

\author{
Oscar O. Ortiz-Rodriguez ${ }^{1}$, Carlos A. Naranjo², Rafael G. García-Caceres ${ }^{3} \&$ Raquel A. Villamizar-Gallardo \\ ${ }^{1}$ Departamento de Ingeniería Industrial/Universidad de Pamplona. Pamplona, Colombia. E-mail: oscarortiz@unipamplona.edu.co (Corresponding author) \\ ${ }^{2}$ División Sostenibilidad/GAIA Servicios Ambientales. Antioquia, Colombia. E-mail: cnaranjo@gaiasa.com \\ ${ }^{3}$ Vicerrectoría de Investigaciones/Universitaria Agustiniana. Pamplona, Colombia. E-mail: rafael.garcia@uniagustiniana.edu.co \\ ${ }^{4}$ Departamento de Microbiología/Universidad de Pamplona. Pamplona, Colombia. E-mail: raquel.villamizar@gmail.com
}

\section{Key words:}

climate change

cocoa

evapotranspiration

fresh water

Theobroma cacao L.

\begin{abstract}
A B S T R A C T
The main objective of the present research was to calculate the water footprint of the Colombian cocoa (Theobroma cacao L.) production. The evaluation of crop water requirement and irrigation requirement were based on climate, soil and crop conditions in the country. The water requirement estimation was based on data from six municipalities selected for their representativeness of the highest yield, productivity and commercial dynamics of the country. The results show that the Water footprint reached $17,100 \mathrm{~m}^{3} \mathrm{t}^{-1}$. At the province level, the highest record for this parameter was observed in Tolima, with 23,239 $\mathrm{m}^{3} \mathrm{t}^{-1}$, while Huila registered the lowest level, with $13,475 \mathrm{~m}^{3} \mathrm{t}^{-1}$. Water use per crop unit can be influenced not only by agro-meteorological conditions, but also by the level of production. Therefore, a region with a low water footprint value for a specific crop usually has a favorable climatic condition. Crop evapotranspiration was found to be relatively low, and the highest yields were obtained in association with more productive cropping levels. Given the complexity of a hydrological phenomenon like crop evapotranspiration, the magnitude of these differences may be considered to be small.
\end{abstract}

\section{Palavras-chave: \\ alterações climáticas \\ cacau \\ evapotranspiração \\ água doce \\ Theobroma cacao L.}

\section{Avaliação de pegada hídrica da produção de cacau colombiano}

\section{R E S U M O}

O objetivo principal da presente pesquisa é avaliar a pegada hídrica da produção do cacau Colombiano (Theobroma cacao L.). A exigência hídrica da cultura, tanto quanto a de irrigação, foi avaliada com base nas condições de clima, solo e da cultura no país. A estimativa da necessidade de água foi baseada em dados de seis municípios selecionados pela representatividade dos seus maiores níveis de rendimento, produtividade e dinâmica comercial do Brasil. De acordo com os resultados a pegada hídrica atingiu 17,100 $\mathrm{m}^{3} \mathrm{t}^{-1}$. A nível de província, o maior recorde para este parâmetro foi observado em Tolima com $23,239 \mathrm{~m}^{3} \mathrm{t}^{-1}$ enquanto Huila registrou o nível mais baixo, com 13,475 $\mathrm{m}^{3} \mathrm{t}^{-1}$. O consumo de água por unidade de cultura pode ser influenciado não só pelas condições agrometeorológicas, mas também pelo nível de produção; portanto, regiões com baixos valores de pegada hídrica para uma cultura específica geralmente têm condição climática favorável. A evapotranspiração é relativamente baixa e os maiores rendimentos foram obtidos na agricultura com maiores níveis de produção; em razão da complexidade de um fenômeno hidrológico, como a evapotranspiração de uma cultura, a magnitude dessas diferenças pode ser considerada pequena. 


\section{INTRODUCTION}

Growth in the agricultural sector is essential for achieving the Millennium Development Goals (MDGs) of eradicating hunger and poverty (Rockström et al., 2010). As the primary consumer of water resources around the world, agriculture is being increasingly squeezed by the demands from other society sectors and threatened by potential climate change (Sun et al., 2013; Thorburn, 2013). Furthermore, water availability is a critical concern to future food security and environmental sustainability (Ridoutt et al., 2010). Therefore, one of the greatest constraints on current and future food production is availability of fresh water, which is now a scarce and overexploited resource in many parts of the world (Kirby et al., 2003; Gordon et al., 2010).

Data shows that at the current rates of agricultural water use efficiency, an additional amount of fresh water (estimated in $5,700 \mathrm{~km}^{3}$ year $^{-1}$ ) will be needed to meet the food demand by 2050 . These researches have also expressed the global consumption of this liquid on the part of food production in approximately $7,100 \mathrm{~km}^{3}$ year ${ }^{-1}$, out of which $5,500 \mathrm{~km}^{3}$ year-1 are used in rainfed agriculture and $1,600 \mathrm{~km}^{3}$ year-1 $^{-1}$ in irrigated agriculture (Fraiture et al., 2007).

The water footprint is an indicator of fresh water use that looks not only at direct water use of a consumer or producer, but also at the indirect water use (TCCC \& TNC, 2010). Introduced by Hoekstra \& Hung (2002), and subsequently elaborated by Chapagain \& Hoekstra (2004), Water Footprint (WF) is currently a well known tool to assess water use throughout the supply chain, thus providing valuable insight on the largest water consumption components, their geographical location and potential effects on local watersheds and future water availability, so as to serve the needs of communities, nature, companies, producers and suppliers.

To date, however, limited research has been published on the amount of fresh water embodied in crop production (Francke \& Castro, 2013) and there is a necessity worldwide to deploy knowledge and skills due to the consideration within the agricultural sector is heavily impacted by climate change and that the consequent yield reduction may result in food security decline worldwide (Olesen \& Bindi, 2002; Gondim et al., 2008).

Nevertheless, a review of the existing literature shows that there have been various studies dealing with the assessment of WF as an indicator of fresh water use in different sectors, namely energy (Gerbens-Leenes et al., 2008), construction (Solís-Guzmán et al., 2013), tourism (Cazcarro et al., 2014), and agriculture. This consideration is currently receiving more and more attention (Chapagain \& Hoekstra, 2007; Ertug-Ercin et al., 2011; Andreea et al., 2013; Ruini et al., 2013).

For instance, in 2011 Hoekstra assessed rice WF in terms of green, blue and grey water, making use of high spatial resolution data on local irrigation. In studying sugarcane and cassava WF in northern Thailand, Kongboon \& Sampattagul (2012) found differences in the amounts of freshwater use determined by several factors, which included climate, crop characteristics and agricultural production system, all of which vary depending on the region. Bocchiola et al.
(2013) analysed WF in the Po valley, which is one of the most productive agricultural areas within Europe maize fields. Sun et al., (2013) calculated the major crop WF in the Hetao irrigation district (China). Vanham \& Bidoglio, (2013) recently carried out a literature survey on the WF indicator and its applicability to EU28. While these studies describe various WF in some European countries and China, there is a need to estimate WF in commercial crop in the tropics, especially in Latin American countries, since targeting areas of improvement is a worthwhile effort to find potential solutions and to contribute to a better management of water resources (Aldaya et al., 2010).

Cocoa (Theobroma cacao L) is a very popular fruit due to the fact that all kinds of chocolates and confectionaries are made from its beans. It is a tropical crop originated from Central and South America grown under humidity conditions that produces from 0.5 to $2 \mathrm{~kg}$ of dried and fermented cocoa beans per tree annually (Medeiros \& lannes, 2010). Currently, Colombia is the fifth producer worldwide and the third one in Latin America. According to the Colombian Federation of Cocoa Growers (Fedecacao, 2013), the "Cocoa Development Ten Year Plan 2012 - 2021", the area planted with this crop at national level was 158,000 ha in 2012 , yielding $50,000 \mathrm{t}$ of this product and there are 660,000 hectares available for growing this crop. Requiring an investment of $\$ 2.5$ billion (Colombian peso) in the next ten years, these lands production is projected to reach $246,000 \mathrm{t}$ by the year 2021 . Therefore, in this paper the main objective was to calculate the water footprint (WF) of the Colombian cocoa production using the international methodology of water footprint network, of which takes into account the water volumes. In this sense, this research is one of the first applying water footprint of the cocoa production, especially in Colombia, a country under development. Finally, this paper can be used as a preliminary study evaluating possible water management guidelines, so as to provide new data for diverse stakeholders such as farmers, engineers, environmentalists, governmental agencies and Life Cycle Assessment advisors in order to promote the use of WF within the Colombian industry.

\section{Material ANd Methods}

The water requirement estimation for cocoa production in Colombia was based on data from six municipalities selected for their representativeness with the highest yield, productivity and commercially dynamic regions of the country. So the municipalities of Santander with $40.7 \%$ of the total production, Huila with $11.5 \%$, Nariño (10.9\%), Tolima (8.1\%), Antioquia (5.3\%) and Arauca with 5.0\% were taken into consideration.

The estimation of real evapotranspiration (ETr: transpiration through plant stomata plus water evaporation from the soil surface) in cocoa was based on criteria presented in "The Water Footprint Assessment Manual” (Hoekstra et al., 2011), using the CROPWAT computational model, which has been developed by the FAO (Food and Agriculture Organization of the United Nations). In this paper, two alternatives such as Crop Water Requirement (CWR) and Irrigation Programming 
for the estimation of green and blue evapotranspiration water throughout the different stages of a crop have been considered.

So, CWR was based on the assumption that there were no water limitations for crop growth (the ideal moisture conditions are satisfied by rain or irrigation). This option calculated three elements: a) crop water requirements under specific climate conditions; b) effective precipitation (the amount of water, which, not having being lost by interception or runoff is effectively available for the plant); and c) irrigation needs in case that the rain does not supply all the requirements. The Evapotranspiration, both green which is the volume of rainwater consumed during the production process and blue which is the volume of surface and groundwater consumed as a result of the production of a good or service, were estimated in terms of Length/time.

$$
\begin{gathered}
\mathrm{ET}_{\text {green }}=\min \left(\mathrm{ET}_{\mathrm{c}}, \mathrm{P}_{\text {ef }}\right) \\
\mathrm{ET}_{\text {blue }}=\max \left(0, \mathrm{ET}_{\mathrm{c}}-\mathrm{P}_{\text {ef }}\right) \\
\mathrm{ET}_{\mathrm{c}}=\mathrm{CWE}=\mathrm{K}_{\mathrm{c}} \cdot \mathrm{ET}_{0}
\end{gathered}
$$

where:

$\mathrm{P}_{\mathrm{ef}} \quad$ - effective precipitation;

ET $_{c}$ - total crop evapotranspiration (Eqs. 1, 2, and 3);

$\mathrm{K}_{\mathrm{c}} \quad$ - crop specific coefficient; and

$\mathrm{ET}_{0}$ - evapotranspiration of the reference crop (Hoekstra et al., 2011).

$\mathrm{ET}_{0}$ was estimated through the Penman-Montieth method (FAO, 2015). However, in face of the lack of specific methods for the calculation of effective precipitation in Colombia, this parameter was estimated through the method of the Soil Conservation Service of the United States Department of Agriculture (USDA, SCS) using the Eq. 4:

$$
\mathrm{P}_{\mathrm{ef}}=125+0.1 \cdot \mathrm{P}_{\text {monthly }}, \text { for } \mathrm{P}_{\text {monthly }}>250 \mathrm{~mm}
$$

In order to calculate green and blue evapotranspiration water, the following assumptions have been made:

A soil moisture balance is included, together with a crop evapotranspiration correction, which is implemented when soil moisture conditions are not optimal. So, the adjusted crop evapotranspiration (ET $\mathrm{a}_{\mathrm{a}}$ ) was estimated in terms of Length/ time and was calculated using Eqs. 5 and 6.

$$
\begin{gathered}
\mathrm{ETa}=\mathrm{K}_{\mathrm{s}} \cdot \mathrm{ET}_{\mathrm{c}}=\mathrm{K}_{\mathrm{s}} \cdot \mathrm{K}_{\mathrm{c}} \cdot \mathrm{ET}_{0} \\
\mathrm{~K}_{\mathrm{s}}=\frac{(\mathrm{ADT}-\mathrm{Dr})}{(\mathrm{ADT}-\mathrm{AFA})}
\end{gathered}
$$

where:

$\mathrm{K}_{\mathrm{s}}$ - water stress coefficient, which is lesser than 1 under hydric stress conditions (thus affecting optimal crop evapotranspiration $\mathrm{ET}_{\mathrm{c}}$ ) and equals 1 in the opposite case);

ADT - total available water (the difference in soil moisture content between Field Capacity and Permanent Wilting Point);
Dr - root zone depletion (the amount of water that is missing with respect to Field Capacity); and

AFA - easily usable water (the fraction of total available water before water stress).

When a crop receives no irrigation (rainfed cultivation), the CROPWAT simulation uses the "non-irrigation" condition, where $\mathrm{ET}_{\text {green }}$ is equivalent to total evapotranspiration as simulated by the model, and $\mathrm{ET}_{\text {blue }}$ equals zero.

In either case, the green component of the crop's water footprint was estimated through Eq. 7 , in which $\mathrm{CWU}_{\text {green }}$ : green component of crop water usage $\left(\mathrm{m}^{3} \mathrm{ha}^{-1}\right)$, and Y: crop yield ( $\left.\mathrm{t} \mathrm{ha}^{-1}\right)$ (Hoekstra et al., 2011).

$$
\mathrm{WF}_{\text {green }}=\frac{\mathrm{CWU}_{\text {green }}}{\mathrm{Y}}
$$

Data regarding the climate, soil and crop information were calculated for a calendar year based on monthly average hydrological data from IDEAM (Colombian Institute for Hydrology, Meteorology and Environmental Studies), corresponding to the $2000-2012$ period. So, the necessary climate information input for CROPWAT 8.0 was made up of consolidated monthly data on maximum and minimum temperatures and average records of precipitation, humidity and wind speed. This data were obtained from records of the climate stations operated by IDEAM. Additionally, the data from the closest CLIMWAT (global climate database developed by the FAO to be jointly operated with the CROPWAT model) station to the studied area were taken into consideration to complete the records.

The climate time series in question were subjected to basic information quality analysis through the construction of simple mass curves, in order to assess changes in mean values (Subramanya, 1994); and through the estimation of missing values, using all available data, so as to assess the quality of the results as obtained from the climate records.

Finally, soil texture data were obtained from corresponding maps of each municipality (scale: 1:250000), elaborated by IGAC (Geographic Institute Agustín Codazzi). Based on these data, the SPAW (Soil Water Characteristics Program) model developed by Saxton \& Willey (2005) and Saxton \& Rawls (2006), was applied to estimate field capacity and permanent wilting point. These parameters were calculated from texture, salinity, compactation and organic matter contents. As only the texture data were available, in all cases a salinity of $0 \mathrm{dS} \mathrm{m}^{-1}$, a normal degree of compactation and an organic matter content of $2.5 \%$ were considered, all of which are baseline values suggested by the model to make the estimations.

Others parameters such as the field capacity and permanent wilting point values for the different textures of each municipality were obtained to calculate average results based on the area covered by each texture. For such purpose, geographic information system GIS 1.8 was used. Finally, the information about cocoa cultivation, which consisted in the crop's coefficient, it is phenological stages (days), root 
depth and critical depletion were also took into account. Tree height for the two genetic classes grown in Colombian plantations such as $7 \mathrm{~m}$ height native trees yields $450 \mathrm{~kg} \mathrm{ha}^{-1}$, and $4 \mathrm{~m}$-height newly-bred trees yielding $1,200 \mathrm{~kg} \mathrm{ha}^{-1}$ have been considered to calculate the WF of the Colombian cocoa production.

Finally, in this paper, the grey water footprint is out of scope because during the cultivation phase of the farmer, as this is not a common agriculture practices in the Colombian farmers. Nevertheless, the WFN has computed the grey water footprint for the world and data shows that it is less than $1 \%$ of the total water footprint and can vary largely among rivers (Liu wt al., 2012).

\section{Results AND Discussion}

It is presented the Crop $\mathrm{WF}_{\text {Green }}$ results obtained through the application of the two calculation alternatives for this parameter within the CROPWAT model (Table 1). The water footprint of Colombian cocoa cultivation as measured in $\mathrm{m}^{3} \mathrm{t}^{-1}$ of cocoa beans has been shown to range between 13,475 and $23,239 \mathrm{~m}^{3} \mathrm{t}^{-1}$, depending on the production site, its environmental conditions and agricultural techniques. Besides an overall increase of the total production water footprint, this would specifically raise the blue and grey water footprints per unit of product.

The differences in the values of this parameter, obtained through the CWR method were $4.25 \%$ for the municipality of Apartadó (Antioquia), 7.23\% for Tame (Arauca), 1.64\% in Garzón (Huila), - $0.30 \%$ Tumaco (Nariño), 3.78\% in San Vicente (Santander), and $4.87 \%$ Chaparral (Tolima). Given the complexity of a hydrological phenomenon like crop evapotranspiration, the magnitude of these differences can be said to be small.

Results also show that the values obtained with the CWR method are lesser in five of the six studied municipalities, except for Chaparral. This reveals that uncertainty in the estimation of the soil-related hydric balance parameters did affect the final results, because the remaining parameters (crop and climate related ones) are the same in both calculation methods. Based on these considerations, the subsequent Crop Water Use Green estimations $\left(\mathrm{CWU}_{\text {green }}\right)$ were based on the CWR method.

$\mathrm{WF}_{\text {green }}$ estimation was based on the productivity of the two genetic classes in question (new materials: $1,200 \mathrm{~kg} \mathrm{ha}^{-1}$; and native materials: $450 \mathrm{~kg} \mathrm{ha}^{-1}$ ). This value was weighed according to the participation of each tree class in the total planted area of the studied municipalities (Table 2).

Table 1. Results of the $W F_{\text {green }}$ in $\mathrm{m}^{3} \mathrm{t}^{-1}$ for the Colombian cocoa production

\begin{tabular}{lccc}
\hline \multirow{2}{*}{ Municipalities } & \multicolumn{2}{c}{ Tree } & \multirow{2}{*}{ Total $\mathbf{W F}_{\text {green }}$} \\
\cline { 2 - 3 } Apartadó (Antioquia) & $\mathbf{4 ~} \mathbf{~ m}$ & $\mathbf{7 ~} \mathbf{~ m}$ & \\
Tame (Arauca) & 9,488 & 25,153 & 14,344 \\
Garzón (Huila) & 8,096 & 21,542 & 15,057 \\
Tumaco (Nariño) & 6,010 & 15,617 & 13,475 \\
San Vicente (Santander) & 8,525 & 22,564 & 13,719 \\
Chaparral (Tolima) & 10,208 & 27,122 & 22,758 \\
\hline
\end{tabular}

Table 2. Comparison of the results obtained by the two calculation options of the CROPWAT method in $\mathrm{m}^{3} \mathrm{ha}^{-1}$

\begin{tabular}{|c|c|c|c|c|}
\hline \multirow{3}{*}{ Municipalities } & \multicolumn{2}{|c|}{ Irrigation programing } & \multicolumn{2}{|c|}{ CWR $^{*}$} \\
\hline & \multicolumn{4}{|c|}{ Tree } \\
\hline & $4 \mathrm{~m}$ & $7 \mathrm{~m}$ & $4 \mathrm{~m}$ & $7 \mathrm{~m}$ \\
\hline Apartadó (Antioquia) & 11,869 & 11,800 & 11,386 & 11,319 \\
\hline Tame (Arauca) & 10,418 & 10,395 & 9,716 & 9,694 \\
\hline Garzón (Huila) & 7,340 & 7,134 & 7,212 & 7,028 \\
\hline Tumaco (Nariño) & 10,200 & 10,123 & 10,230 & 10,154 \\
\hline San Vicente (Santander) & 12,713 & 12,666 & 12,250 & 12,205 \\
\hline Chaparral (Tolima) & 12,594 & 12,575 & 12,008 & 11,993 \\
\hline
\end{tabular}

* CWR - Crop water requirement

On the other hand the percent distributions of the two cocoa tree types planted in the municipalities are presented in Table 3.

According to Vanham \& Bidoglio (2013), coffee and cocoa are two water intensive products that have elevated virtual water contents. In this sense, Ridoutt \& Pfister (2010) observed that the growth of cocoa beans consumes large amounts of green water. However, cocoa is typically grown as a tropical rainforest understory crop and it is questionable whether there would be any additional stream flow or groundwater recharge in the absence of production.

Furthermore, previous results also show that the water use efficiency by the crop can be influenced not only by agro meteorological conditions, but also by production levels. The crop's WF mainly depends on agronomic management and not on regional climate, because cocoa does not receive irrigation nor large amounts of fertilizers or pesticides. Regarding the global impact of climate change, this poses an elevated risk, which, associated to the phenomenon of "El niño", produces considerable drought, thus largely affecting production (Ortiz et al., 2014).

In this context, some water resources management improvement proposals which could be fruitfully used with special emphasis on food security and water scarcity are:

Currently there is availability of cocoa varieties yielding up to $1,500 \mathrm{~kg} \mathrm{ha}^{-1}$, which, compared to the $300 \mathrm{~kg} \mathrm{ha}^{-1}$ records of the local varieties, are considerably more efficient because they use the same amount of green water (rainfall) to produce these significantly higher yields. Secondly, the aforementioned possibility to reduce the water footprint by increasing productivity can be supported through incentivizing policies. Just as there are green flower and green gold initiatives, policies incentivizing the commercialization of more sustainable products shall come to be important cornerstones in water resource management. Thirdly, the water footprint concept

Table 3. Percent distribution of the two cocoa tree types planted in the studied municipalities

\begin{tabular}{|c|c|c|}
\hline \multirow{3}{*}{ Municipalities } & \multicolumn{2}{|c|}{ Tree } \\
\hline & $4 \mathrm{~m}$ & $7 \mathrm{~m}$ \\
\hline & \multicolumn{2}{|c|}{$\%$ of the total crop } \\
\hline Apartadó (Antioquia) & 69.0 & 31.0 \\
\hline Tame (Arauca) & 50.4 & 49.6 \\
\hline Garzón (Huila) & 22.3 & 77.7 \\
\hline Tumaco (Nariño) & 63.0 & 37.0 \\
\hline San Vicente (Santander) & 25.8 & 74.2 \\
\hline Chaparral (Tolima) & 20.5 & 79.5 \\
\hline
\end{tabular}


can be used to introduce "low impact cocoa" in markets that are prone to support initiatives with reduced impact on hydric resources. In effect, the notion of high yield coupled to low water consumption might be the key to exporting a more responsible cocoa in terms of water resources.

Finally, for the evaluation of the water footprint, the present study integrates information from various sources, which adds a degree of uncertainty. Data for climate and precipitation used in the software CROPWAT (e.g. average rainfall, maximum temperature, minimum temperature, air humidity, daily sunshine) and also data regarding variables for soil storage capacity and hydraulic conductivity were necessary. Despite all of this, it is important to note that the objective of this study was to perform WF within the agriculture sector. So, WFs are sought worldwide and this methodology is not a utopian tool to deploy in developing countries. Although the procedure for computing the irrigated WF is flawed because it assumes no water stress, yet yields are often low. This is inconsistent with plant physiology and since the best selection of crop depends on water availability, land, labour and capital availability of the specific WF indicator really tells nothing of value (Chris, 2014). It is, therefore important to apply the nascent WF methodology in both developed and developing countries to allow sustainable water management (Mekonnen \& Hoekstra, 2012). Finally, the present article, though not claiming to be exhaustive, demonstrates the progressive evolution of water footprint in the agriculture sector.

\section{Conclusions}

1. The potential of cocoa production to contribute to water scarcity is probably very small.

2. The performance in water use per unit of crops can be influenced not only by the agro-meteorological conditions, but also by the level of production.

3. The region with low WF value for a specific crop usually has a favorable climatic condition.

4. Crop evapotranspiration is relatively low, and highest yields were obtained in agriculture with higher levels of production, in other words is improved in 1,200 $\mathrm{t} \mathrm{ha}^{-1} \mathrm{yr}^{-1}$ on native $450 \mathrm{t} \mathrm{ha}^{-1}$ $\mathrm{yr}^{-1}$, as with the same rain more cocoa is obtained.

\section{ACKNowledgements}

To the Colombian Administrative Department of Science, Technology, and Innovation - COLCIENCIAS -, Inter-American Development Bank (IDB) and World Bank (WB) BIRF, for to the financial support "Project Reference 0371- 2012" and also the Colombian National Company of Chocolates for providing data, and to the Escuela Colombiana de Ingeniería Julio Garavito for its support.

\section{Literature Cited}

Aldaya, M.; Martinez-Santos, P.; Ramón-Llamas M. Incorporating the Water Footprint and Virtual Water into Policy: Reflections from the Mancha Occidental Region, Spain. Water Resource Management, v.24, p.941-958, 2010. http://dx.doi.org/10.1007/ s11269-009-9480-8
Andreea, E. S; Teodosiu, C.; Robu, B.; Volf, I. Water footprint assessment in the winemaking industry: a case study for a Romanian medium size production plant. Journal of Cleaner Production, v.43, p.122-135, 2013. http://dx.doi.org/10.1016/j. jclepro.2012.11.051

Bocchiola, D.; Nana, E.; Soncini, A. Impact of climate change scenarios on crop yield and water footprint of maize in the Po valley of Italy. Agricultural Water Management, v.116, p.50-61, 2013. http:// dx.doi.org/10.1016/j.agwat.2012.10.009

Cazcarro, I.; Hoekstra, A.Y.; Chóliz, J.S. The water footprint of tourism in Spain. Tourism Management, v.40, p.90-101, 2014. http:// dx.doi.org/10.1016/j.tourman.2013.05.010

Chris, P. Water footprints: Path to enlightenment, or false trail? Agricultural Water Management, v.134, p.119-125, 2014. http:// dx.doi.org/10.1016/j.agwat.2013.12.004

Chapagain, A. K.; Hoekstra A.Y. Water footprints of nations. Value of Water Research Report Series, v.16. 2004, UNESCO-IHE, Delft, the Netherlands. http://www.waterfootprint.org, 23 Jun. 2011.

Chapagain, A. K; Hoekstra, A. Y. The water footprint of coffee and tea consumption in the Netherlands. Ecological Economy, v.64, p.109-118, 2007. http://dx.doi.org/10.1016/j.ecolecon.2007.02.022

Ertug-Ercin, A.; Aldaya, M.M.; Hoekstra, A.Y. Corporate water footprint accounting and impact assessment: The case of the water footprint of a sugar-containing carbonated beverage. Water Resource Management, v.25, p.721-741, 2011. http://dx.doi. org/10.1007/s11269-010-9723-8

FAO - Crop evapotranspiration - Guidelines for computing crop water requirements. Natural Resources Management and Environment Department. Chapter 2 - Penman-Monteith equation. Retrieved from http://www.fao.org/docrep/x0490e/x0490e06.htm, 10 May. 2015.

Fedecacao - Colombian Federation of Cocoa Growers. The Ten Year Cocoa Growing Development Plan for Colombia 2012-2021. Retrieved from http://conectarural.org/sitio/material/plannacional-de-desarrollo-cacaotero-2012\%E2\%80\%932021, 23 Jan. 2013.

Fraiture, C. de; Wichelns, D.; Rockström, J. Looking ahead to 2050: Scenarios of alternative investment approaches. In: Molden, D. (ed.), Water for food, water for life: A comprehensive assessment of water management in agriculture. London: International Water Management Institute, 2007. p.91-145.

Francke, I. C.; Castro, J. F. Carbon and water footprint analysis of a soap bar produced in Brazil by Natura Cosmetics. Water Resources and Industry. v.1-2, p.37-48, 2013. http://dx.doi.org/10.1016/j. wri.2013.03.003

Gerbens-Leenes, P. W.; Hoekstra, A. Y.; Meer van der T. H. The water footprint of energy from biomass: A quantitative assessment and consequences of an increasing share of bio-energy in energy supply. Ecological Economics, v.68, p.1052-1060, 2008. http:// dx.doi.org/10.1016/j.ecolecon.2008.07.013

Gondim R. S.; Holanda, M. A.; de Medeiros S. R. Climate change and impacts on water requirement of permanent crops in the Jaguaribe Basin, Ceará, Brazil. Pesquisa Agropecuária Brasileira, v.43, p.1657-1664, 2008. http://dx.doi.org/10.1590/S0100204X2008001200003

Gordon, L. J; Finlayson, C. M; Falkenmark M. Managing water in agriculture for food production and other ecosystem services. Agricultural Water Management, v.97; p.512-519, 2010. http:// dx.doi.org/10.1016/j.agwat.2009.03.017 
Hoekstra, A. Y.; Chapagain, A. K.; Aldaya, M. M: Water Footprint Assessment Manual - Setting the Global Standard. Earth scan, Enschede. ISBN: 978-1-84971-279-8, http://www.waterfootprint. org/?page=files/WaterFootprintAssessmentManual. 4 May 2011.

Hoekstra A.Y.; Hung P. Q. Virtual water trade: a quantification of virtual water flows between nations in relation to international crop trade. Value of Water Research, Delft: UNESCO-IHE, 2002. 120p. Report Series, v.11.

Kirby, R. M.; Bartram, J.; Carr, R. Water in food production and processing: quantity and quality concerns. Food Control, v.14, p.283-299, 2003. http://dx.doi.org/10.1016/S0956-7135(02)00090-7

Kongboon, R.; Sampattagul, S. The water footprint of sugarcane and cassava in northern Thailand. Proceedings - Social and Behavioral Sciences. v.40, p.451-460, 2012.

Liu, C.; Kroeze C.; Hoekstra A.H.; Gerbens-Leenes W. Past and future trends in grey water footprints of anthropogenic nitrogen and phosphorus inputs to major world rivers. Ecological Indicators, v.18, p.42-49, 2012. http://dx.doi.org/10.1016/j.ecolind.2011.10.005

Medeiros, M. L.; Lannes, S. C. Propriedades físicas de substitutos do cacau. Food Science and Technology, v.30, p.243-253, 2010. http:// dx.doi.org/10.1590/S0101-20612010000500037

Mekonnen, M. M.; Hoekstra, A. Y. National water footprint accounts: the green, blue and grey water footprint of production and consumption, Value of Water Research Report Series No.50, UNESCO-IHE.http://www.waterfootprint.org/?page=files/ WaterStat-NationalWaterFootprints 16 Sep. 2012.

Olesen, J.; Bindi, M. Consequences of climate change for European agricultural productivity, land use and policy. European Journal of Agronomy, v.16, p.239-262, 2002. http://dx.doi.org/10.1016/ S1161-0301(02)00004-7

Ortiz-R, O.; Villamizar-Gallardo, R.; Rangel, M. Applying life cycle management of colombian cocoa production. Food Science and Technology, v.34, p.62-68, 2014. http://dx.doi.org/10.1590/ S0101-20612014005000006

Ridoutt, B. G; Juliano, P; Sanguansri, P; Sellahewa, J. The water footprint of food waste: case study of fresh mango in Australia. Journal of Cleaner Production, v.18, p.1714 - 1721, 2010. http:// dx.doi.org/10.1016/j.jclepro.2010.07.011

Ridoutt, B. G.; Pfister, S. A. Revised approach to water footprinting to make transparent the impacts of consumption and production on global freshwater scarcity. Global Environmental Change, v.20, p.113-120, 2010. http://dx.doi.org/10.1016/j.gloenvcha.2009.08.003
Rockström J.; Karlberg, L; Wani. S; Barron, J.; et al. Managing water in rainfed agriculture the need for a paradigm shift. Agricultural Water Management, v.97, p.543-550, 2010. http://dx.doi. org/10.1016/j.agwat.2009.09.009

Ruini, L.; Marino, M.; Pignatelli, S.; Laio, F.; Ridolfi L. Water footprint of a large-sized food company: The case of Barilla pasta production. Water Resources and Industry, v.1-2, p.7-24, 2013. http://dx.doi.org/10.1016/j.wri.2013.04.002

Saxton, K. E.; Rawls, W. J. Soil water characteristic estimates by texture and organic matter for hydrologic solutions. Soil Science Society of America Journal, v.70, p.1569-1578, 2006. http://dx.doi. org/10.2136/sssaj2005.0117

Saxton, K. E; Willey, P. The SPAW Model for agricultural field and pond hydrologic simulation. In: Frevert, D.; Singh, V. (ed.), Book watershed models. CRC Press Boca Raton, ch17, 2005. p.400-435. http://dx.doi.org/10.1201/9781420037432.ch17

Solís-Guzmán, J.; Marrero, M.; Ramírez-de-Arellano, A. Methodology for determining the ecological footprint of the construction of residential buildings in Andalusia (Spain). Ecology Indicator, v.25, p.239-249, 2013. http://dx.doi.org/10.1016/j. ecolind.2012.10.008

Subramanya, K. Engineering hydrology. II. (ed.), New York: McGrawHill. ch3, 1994. 392p.

Sun, S.; Wu P.; Wang, Y.; Zhao, X. The impacts of interannual climate variability and agricultural inputs on water footprint of crop production in an irrigation district of China. Science of the Total Environment, v.444, p.498-507, 2013. http://dx.doi.org/10.1016/j. scitotenv.2012.12.016

TCCC, TNC. Product water footprint assessments: Practical application in corporate water stewardship. The Coca-Cola Company/The Nature Conservancy, Atlanta, USA, Arlington, USA. http://moderncms.ecosystemmarketplace.com/repository/ moderncms_documents/tccc_tnc_waterfootprintassessments. pdf 6 Apr. 2010

Thorburn, P. J.; Wilkinson, S. N.; Silburnc, D. M. Water quality in agricultural lands draining to the Great Barrier Reef: A review of causes, management and priorities. Agricultural Ecosystem Environment, v.180, p.4-20, 2013. http://dx.doi.org/10.1016/j. agee.2013.07.006

Vanham, D.; Bidoglio, G. A review on the indicator water footprint for the EU28. Ecological Indicator, v.26, p.61-75, 2013. http:// dx.doi.org/10.1016/j.ecolind.2012.10.021 